\title{
Phosphorus Doses and Sowing Times Over Agronomic Aspects of Chia
}

\author{
Débora Fernanda Del Moura Soares ${ }^{1}$, Tiago Roque Benetoli da Silva ${ }^{1}$, Rhaízza Lana Pereira Dusheski ${ }^{1}$, \\ Géssica Daiane da Silva ${ }^{1}$, Poliana Tomé Gouveia ${ }^{1}$, Juliana Stracieri ${ }^{1} \&$ Nadia Graciele Krohn ${ }^{1}$ \\ ${ }^{1}$ Universidade Estadual de Maringá, Maringá, PR, Brazil \\ Correspondence: Débora Fernanda Del Moura Soares, Programa de Pós-Graduação em Ciências Agrarias, \\ Universidade Estadual de Maringá, Estrada da Paca s/n (UEM-Fazenda), São Cristóvão, 87502-970, Umuarama, \\ PR, Brazil. E-mail: deboramoura.s@hotmail.com
}

\author{
Received: August 2, 2018 \\ Accepted: October 7, $2018 \quad$ Online Published: December 15, 2018 \\ doi:10.5539/jas.v11n1p174 \\ URL: https://doi.org/10.5539/jas.v11n1p174
}

\begin{abstract}
Chia (Salvia hispanica L.) is an herbaceous annual plant considered a natural source of Omega 3 and 6 fatty acids, fiber, protein and antioxidants. However, the cultivation in Brazil is still recent and existing technical information and recommendations are limited, especially regarding to fertilization and sowing season. The present work had as objective to evaluate the effect doses application of phosphorus and sowing times over productive and reproductive parameters. The experiment was conducted in greenhouse conditions at Fazenda da Universidade Estadual de Maringa, Campus Umuarama. The soil used for the experiment is a typical Distrofic Red Latosoil, with sandy texture. The experimental design was entirely in factorial scheme $4 \times 4$ with three replications. Treatments were composed of four seeding seasons, at intervals of 15 days between one and another with four doses of $\mathrm{P}_{2} \mathrm{O}_{5}$ applied at seeding $\left(0,40,80\right.$ and $120 \mathrm{~kg} \mathrm{ha}^{-1}$, totalizing 48 plots units. It was evaluated the following parameters dry mass of root and shoot, grain yield, mass of 1,000 grains and oil content. There were no significant results both for phosphorus doses as for interaction in any of the variables evaluated. The treatment seeding times (E) differed statistically only for grain yield.
\end{abstract}

Keywords: Salvia hispanica L., phosphorus fertilization, oleaginous species

\section{Introduction}

Salvia hispanica L., named as chia, belongs to Lamiaceas family, is a shrubby and herbaceous annual plant, tropical and temperate (Ayerza \& Coates, 2006). The first reports of this plant were in Central Southern Mexico and Northern Guatemala, where, for many years it was used for food, medicinal plant and even "commodity" (Busilacchi et al., 2013; Migliavacca et al., 2014a). With Spanish colonization also came the exclusion of chia cultivation, remaining present in some small villages and thus lasted for many years (Sáez, 2014; Migliavacca et al., 2014a).

The seed is composed of oil, polyunsaturated fatty acids, with Omega 3 and 6 representing greater importance (Sáez, 2014; Ayerza \& Coates, 2006). According to Miranda (2012) in Brazil, chia cultivation is recent, being scarce agricultural management information that leads to follow foreign recommendations for its cultivation. Crop has some restrictions that limit its germination and development, seeds are sensitive to flooded soils, conditions that restrict crop performance by limiting the production potential (Stefanello et al., 2015). Sowing depth and incorrect fertilizing are unfavorable for $S$. hispanica $\mathrm{L}$. about its productive yield that represents the main interest (Migliavacca et al., 2014b). The growing economic interest by chia is increasing in world agriculture; this is due to seeds composition, presenting proteins, lipids and plenty of fiber (Sáez, 2014).

Sowing time is an aspect of great importance that must be considered to deploy a crop, so that environmental conditions are favorable to plants development. Early crops result in better final production, biomass and seed yield (Tomaz et al., 2012). Busilacchi et al. (2013) expose that chia for being classified as a plant of short day and if there is delay in seeding time may occur smaller plants formation and floral induction early. According to Migliavacca et al. (2014b) the production index is better when sowing is performed in October and November months, because of favourable conditions for crop development and performance, highlighting that plants can reach up to 2 meters height and provide production up to $800 \mathrm{~kg}$ per hectare.

Phosphorus is classified as macronutrients, and without it the plant fails to develop properly. This nutrient provides a favorable environment for roots development, besides providing other nutrients in smaller proportion 
such as sulfur, calcium and magnesium, that according to phosphorus source used (Lima et al., 2011; Silveira et al., 2015). Their absorption is by diffusion, action in those roots find during its growth (Elz et al., 2010). According to Hippler et al. (2011) phosphorus acts on productive potential of various species, being essential to plants metabolic processes. Alcantra Neto et al. (2010) verified that the maintenance of soil phosphorus provides better final yield crop. This element is a component of nucleic acids and is directly related to photosynthesis and metabolic processes, as well as other benefits, such as the availability of calcium, magnesium and sulfur (Hippler et al., 2011; Silveira et al., 2015). Alcantra Neto et al. (2010) note that consistent maintenance of phosphorus in the soil ensures the cultivation and significant progress in final production, as well as in helping to absorb water and other nutrients, providing resistance to cold and some diseases.

\section{Methods}

The experiment was conducted in greenhouse conditions at Fazenda belonging to Universidade Estadual de Maringa, Campus de Umuarama, located at $23^{\circ} 47^{\prime} \mathrm{S}$ and $53^{\circ} 14^{\prime} \mathrm{W}$. Weather is classified Cfa, with mean annual temperature of $20.7^{\circ} \mathrm{C}$ and rainfall of $1,512 \mathrm{~mm}$ (Köppen \& Geiger, 1928). The soil used for the experiment is a typical Distrophic Red Latosoil, with sandy texture (EMBRAPA, 2013). The climate of the region is classified as $\mathrm{Cfa}$, for being subtropical, with mean temperature in the coldest month less than $18^{\circ} \mathrm{C}$ (mesothermic) and mean temperature of the hottest month above $22{ }^{\circ} \mathrm{C}$, with hot summers, infrequent frosts and rainfall concentration tendency in summer months, however, without defined dry station (IAPAR, 2014).

Soil analysis was performed by means of samples collected 30 days before experiment implementation, with the determination of certain chemical soil attributes (Table 1). As the result of the analysis was necessary apply dolomite (limestone) to increase saturation bases up to $70 \%$ as indication of Paulettie Motta (2017) and $20 \mathrm{~g}$ 10-00-17 formulated per vase.

Table 1. Chemical soil attributes, before experiment implementation (Umuarama/2017)

\begin{tabular}{|c|c|c|c|c|c|c|c|c|}
\hline $\mathrm{pH}$ & $\mathrm{P}$ & O.M. & $\mathrm{Ca}$ & $\mathrm{K}$ & $\mathrm{Mg}$ & $\mathrm{Al}$ & CTC & $\mathrm{V}$ \\
\hline $\mathrm{CaCl}_{2}$ & $\mathrm{mg} \mathrm{dm}^{-3}$ & $\mathrm{~g} \mathrm{dm}^{-3}$ & - --- & - & - $\mathrm{cmo}$ & - & - & $\%$ \\
\hline 4.35 & 1.0 & 15.04 & 0.72 & 0.1 & 0.21 & 1.35 & 3.88 & 26.55 \\
\hline
\end{tabular}

Note. P and K extracted by Melich method; Organic matter extracted by Walkley-Black method; $\mathrm{Ca}, \mathrm{Mg}$ and $\mathrm{Al}$ extracted with $\mathrm{KCl} 1 \mathrm{cmol} \mathrm{L}^{-1}$.

Seeds were donated by farmers from Paraguay Country. There's not a commercial cultivar, therefore, it was used a common cultivar. Since there is no recommendation of fertilization for chia cultivation, the authors used the basis recommendations to mint (Pauletti \& Motta, 2017), because it belongs to the same botanic family. Phosphorus doses were applied according the treatments.

Each experimental plot consisted of a vase containing 14 liters $(28 \times 28 \times 25 \mathrm{~cm})$, maintaining just one plant per plot. The experimental design was entirely randomized design in factorial scheme $4 \times 4$ with three repetitions. The treatments were composed of four sowing periods, in January, 08 and 23; February, 07 and 22,2017 agricultural year (constituting treatments E1, E2, E3 and E4), with intervals of 15 days between one and another with four doses of $\left.\mathrm{P}_{2} \mathrm{O}_{5}\right)$ applied in sowing $\left(0,40,80\right.$ and $\left.120 \mathrm{~kg} \mathrm{ha}^{-1}\right)$ totaling 48 experimental plots. Crop cycle for each sowing period until harvest was: $\mathrm{E} 1=132, \mathrm{E} 2=117, \mathrm{E} 3=102$ and $\mathrm{E} 4=87$ days.

The harvest was manual, at end of crop cycle, by cutting the aerial part of plants of each experimental plot. After it, grains threshing and cleaning was conducted through sieves, by removing impurities from the harvest to carry out the analysis.

Plant residues, previously separated in shoot and root parts, were brought to oven with forced air circulation remaining for 48 hours in mean temperature of $65^{\circ} \mathrm{C}$ and subsequently data were converted into g plant ${ }^{-1}$, thus obtaining shoot and root dry mass.

Grain yield was obtained through determination of mass of the grains harvested and subsequent conversion to $g$ plant $^{-1}$. Both mass of 1,000 grains as grain yield had it standardized values to $13 \%$ humidity (Brazil, 2009).

For the evaluation of mass of 1,000 grains, seeds were counted and weighed by the means of two repetitions per plot, in precision balance. Seeds oil content was quantified in the laboratory, by extraction methodology with hexane Soxhlet type (IAL, 2008). Data were subjected to variance analysis by F-test, at 1\% significance level. Means from two factors were compared by Tukey test at $5 \%$ probability. 


\section{Results}

The treatment sowing epochs (E) differed statistically only for grain productivity (Table 2). It may be noted by variance analysis highlighting for means of $\mathrm{E} 3=1.23 \mathrm{~g} \mathrm{plant}^{-1}$ and E4 $=1.00 \mathrm{~g} \mathrm{plant}^{-1}$, dated on February, 07 and February, 22 respectively.

Table 2. Root dry matter $\left(\mathrm{g} \mathrm{plant}^{-1}\right)$ and dossel part $\left(\mathrm{g} \mathrm{plant}^{-1}\right)$, mass of 1,000 grains $(\mathrm{g})$, grain yield $\left(\mathrm{g}\right.$ planta $\left.{ }^{-1}\right)$ and oil content (\%) of chia seeds, in function of sowing periods and phosphorus nutrition (Umuarama, Parana State, Brazil, 2017)

\begin{tabular}{|c|c|c|c|c|c|}
\hline Treatment & Root dry masss $^{1}$ & Dossel dry mass $^{1}$ & Grain yield & Mass of a 1,000 grains & Oil content $^{1}$ \\
\hline & 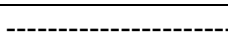 & - g plant $^{-1}$ & 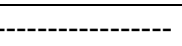 & 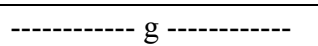 & ------ \% ------ \\
\hline \multicolumn{6}{|l|}{ Epoch } \\
\hline E1 & $1.06 \mathrm{a}$ & $5.02 \mathrm{a}$ & $0.24 \mathrm{c}$ & $0.84 \mathrm{a}$ & $4.08 \mathrm{a}$ \\
\hline E2 & $1.71 \mathrm{a}$ & $7.93 \mathrm{a}$ & $0.56 \mathrm{~b}$ & $0.86 \mathrm{a}$ & $3.50 \mathrm{a}$ \\
\hline E3 & $1.70 \mathrm{a}$ & $9.25 \mathrm{a}$ & $1.23 \mathrm{a}$ & $0.93 \mathrm{a}$ & $3.31 \mathrm{a}$ \\
\hline E4 & $2.17 \mathrm{a}$ & $7.75 \mathrm{a}$ & $1.00 \mathrm{a}$ & $0.80 \mathrm{a}$ & $4.13 \mathrm{a}$ \\
\hline \multicolumn{6}{|c|}{ Phosphorus $\left(\mathrm{kg} h \mathrm{a}^{-1}\right)$} \\
\hline 0 & 1.60 & 7.59 & 0.72 & 0.90 & 4.01 \\
\hline 40 & 1.30 & 5.43 & 0.69 & 0.81 & 3.88 \\
\hline 80 & 2.08 & 9.61 & 1.13 & 0.88 & 3.82 \\
\hline 120 & 1.50 & 7.80 & 0.72 & 0.78 & 3.86 \\
\hline C.V. $(\%)$ & 26.6 & 31.3 & 28.6 & 16.2 & 6.1 \\
\hline
\end{tabular}

Note. ${ }^{1}$ Data transformed by $\sqrt{\mathrm{x}+0.5} ; *$ and n.s. $=$ significative and no significative at $5 \%$ probability; Means followed by the same letter inside epoch parameter does not differ among each other by Tukey test at $5 \%$ significnce level; C.V. $=$ variance coefficient.

\section{Discussion}

The results obtained in this experiment differed from those observed by Tomaz et al. (2012) in a similar experiment to evaluate the effect of sowing times on sunflower cultivation, where there was significant increase of times in achiness' formation.

Treatment with phosphorus doses (Table 2) applied in the soil at seeding did not promote significant results differing from those obtained by Lima et al. (2011) in that increasing phosphorous doses influenced all development characteristics in physic nut seedlings. These results can be explained due to chia genetic variability, aware that a common cultivar was used for the experiment, being unequal in the repetitions. Donson et al. (2002) explain that genetic characteristics are directly relational to biological process as well as environment interactions.

The soil used in the experiment was previously corrected and fertilized and phosphate fertilization performed in one step. However, there was no significant loss of phosphorus, since it was growing in vases and irrigation occurred as were being installed the sowing seasons. So chia remained plants showed well nourished throughout the cycle, without influencing the oil content. According with this, increasing doses of phosphorus is not apparent to chia characteristics, even being a carrier and transducer of adenosine triphosphate (Epstein \& Bloom, 2006).

According to the results (Table 2), E3 and E4 have obtained major productions for the variable grain yield. In similar research Tomaz et al. (2012) observed significant funding in the formation of sunflower achenes when evaluating the sowing season's parameter. According to Jambonsri et al. (2011), chia requires photoperiod less than the maximum and a delay or advance at cultivation time of cultivation has influence the results of yield.

The length of the day was more than the maximum critic crop required (Figure 1). In the early times of sowing, photoperiod regulates many biochemical responses that occur in plants, one of them flowering induction. In short day plants, as chia it must be less than the maximum critical (Taiz \& Zeiger, 2009).

All treatments have reached the harvest point at the same time, since all plants had induced to flourish once the photoperiod reached 12 hours or less. Aguirrezábal et al. (2003) obtained that the variation in the amplitude of day length is linked to seeds formation. According to Figure 1 it is possible to observe that as later is sowing less will be crop cycle even providing satisfactory grain yield. 


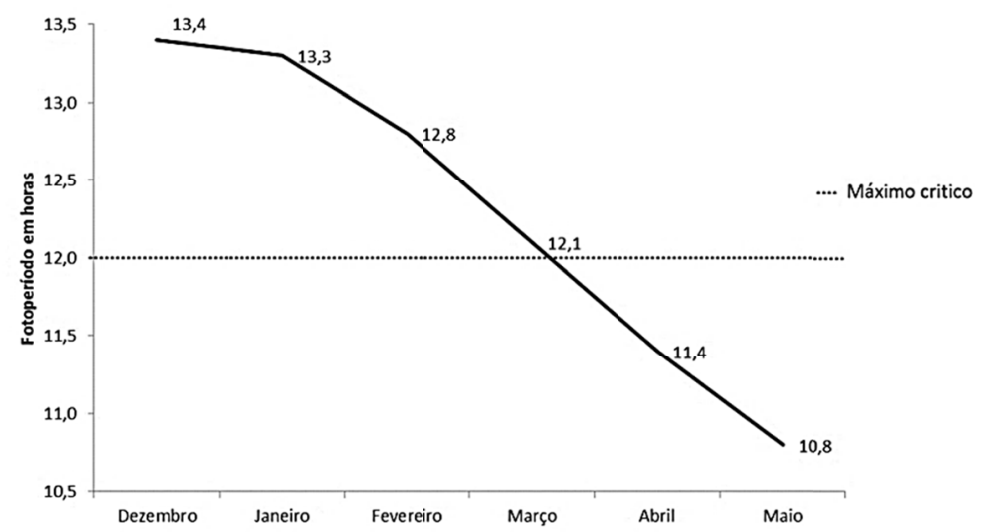

Figure 1. Photoperiod occurred during experiment conduction in Umuarama

Phosphorus doses did not demonstrate statistical significance to any of variables evaluated.

The sowing seasons treatment differed statistically only for grain yield being 07 and 22 February showing bigger yields, reaching values of 1.23 and $1.00 \mathrm{~g} \mathrm{plant}^{-1}$ respectively.

\section{References}

Aguirrezábal, L. A. N., Lavaud, Y., Guillermo A. A. D., Natalia, G. I., Fernando, H. A., \& Leila, M. Go. (2003). Intercepted solar radiation during seed filling determines sunflower weight per seed and oil concentration. Crop Science Society of América, 43(1), 152-161. https://doi.org/10.2135/cropsci2003.1520

Alcantara Neto. F., Gravina, G. A., Souza, N. O. S., \& Bezerra, A. A. C. (2010). Adubação fosfatada na cultura da soja na microrregião do Alto Médio Gurguéia. Revista Ciência Agronômica, 41(2), 266-271. https://doi.org/10.1590/S1806-66902010000200014

Ayerza, R., \& Coates, W. (2006). Chía redescubriendo um olvidado alimento de losaztecas (p. 205). Buenos Aires: Ed. Nuevo Extremo.

Brasil, D. N. P. V. (2009). Regras para análises de sementes (p. 365). Brasília: DVNP-DISEN.

Busilacchi, H., Quiroga, M., Bueno, M., Sapio, O., Flores, V., \& Severin, C. (2013). Evaluación de Salvia hispanica L. cultivada en el sur de Santa Fe (República Argentina). Cultivos Tropicales, 34(4), 55-59.

Donson, J., Fang, Y., Espiritu-Santo, G., Xing, W., Salazar, A., Miyamoto, S., ... Volkmuth, W. (2002). Comprehensive gene expression. analysis by transcript porfiling. Plant Molecular Biology, 48(1-2), 75-97. https://doi.org/10.1023/A:1013722224489

Eltz, F. L. F., Villalba, E. H., \& Lovato, T. (2010). Adubação fosfatada para girassol sob sistema plantio direto no Paraguai. Bragantia, 69(4), 899-904. https://doi.org/10.1590/S0006-87052010000400016

Empresa Brasileira De Pesquisa Agropecuária. (2013). Sistema Brasileiro de Classificação dos Solos (p. 353). Rio de Janeiro: EMBRAPA/CNPSO.

Epstein, E., \& Bloom, A. J. (2006). Nutrição Mineral de plantas: Princípios e perspectivas (p. 402). Londrina: Editora Planta.

Hippler, F. W. R., Moreira, M., Dias, N. M. S., \& Hermann, E. R. (2011). Fungos micorrízicos arbusculares nativos e doses de fósforo no desenvolvimento do amendoim RUNNER IAC 886. Ciência Agronômica, 42(3), 605-610. https://doi.org/10.1590/S1806-66902011000300005

IAL (Instituto Adolfo Lutz). (2008). Métodos fisico-químicos para análise de alimentos (4th ed., p. 1020). São Paulo: Ministério da Saúde.

IAPAR (Instituto Agronômico do Paraná). (2014). Agrometeorologia. Redes de Estações Meteorológicas do Paraná. Estações Meteorológicas Convencionais, Umuarama.

Jamboonsri, W., Phillips, T. D., Geneve, R. L., Cahill, J. P., \& Hildebrand, D. F. (2011). Extending the range of an ancient crop. Salvia hispanica L. a new 13 source. Genetic Resources and Crop Evolution, 59(2), 171-178. https://doi.org/10.1007/s10722-011-9673-x

Köppen, W. R. (1928). Klimate der Erde. Gotha: Verlag Justus Perthes. 
Lima, R. L. S., Severino, L. S., Gheyi, H. R., Sofiatti, V., \& Arriel, N. H. C. (2011). Efeito da adubação fosfatada sobre o crescimento e teor de macronutrientes de mudas de pinhão manso. Revista Ciência Agronômica, 42(4), 950-956. https://doi.org/10.1590/S1806-66902011000400017

Migliavacca, R. A., Silva, T. R. B., Vasconcesos, A. L. S., Mourão Filho, W., \& Baptistella, J. L.C. O. (2014a). cultivo da chia no brasil: futuro e perpectivas. Journal of Agronomic Sciences, 3, 161-179.

Migliavacca, R. A., Vasconcesos, A. L. S., Santos, C. L., \& Baptistella, J. L. C. (2014b). Uso da cultura da chia como opção de rotação no Sistema Plantio Direto (p. 1). Encontro Nacional De Plantio Direto Na Palha, Bonito. Anais... Bonito: FEBRAPDP.

Miranda, F. (2012). Guia tecnica para el manejo del cultivo de chia (Salvia hispanica L.) en Nicaragua (p. 14). Managua: CECOOPSEMEIN.

Pauletti, V., \& Motta, A. C. V. (2017). Manual de adubação e calagem para o estado do Paraná (pp. 419-421). Curitiba: SBCS/NEPAR.

Sáez, H. J. Z. (2014). Monografia: Biología de la chia (Salvia hispanica L.). Faculdad de Ciências Agronomicas, Univerisadad de Chile, Santiago.

Silveira, T. C., Pegoraro, R. F., Portugal, A. F., \& Resende, A. V. (2015). Produção da mamoneira submetida a combinações com fontes de fósforo e calagem. Revista Brasileira de Engenharia Agrícola e Ambiental, 19(1), 52-57. https://doi.org/10.1590/1807-1929/agriambi.v19n1p52-57

Stefanello, R., Neves, L. A. S., Abbad, M. A. B., \& Viana, B. B. (2015). Resposta fisiologia de sementes de chia (Salvia hispanica L.-Lamiales: Lamiaceae) ao estresse salino. Revista Biotemas, 28(4), 35. https://doi.org/ $10.5007 / 2175-7925.2015 \mathrm{v} 28 \mathrm{n} 4 \mathrm{p} 35$

Taiz, L., \& Zeiger, E. (2009). Fisiologia vegetal (4th ed., pp. 714-718). Porto Alegre: Artmed.

Tomaz, G. L., Zagonel, J., Colasante, L. O., \& Nogueira, R. R. (2012). Produção do girassol e teor de óleo nas sementes em diferentes épocas de semeadura no Centro-Sul do Paraná. Ciência Rural, 42(2), 203-208. https://doi.org/10.1590/S0103-84782012005000010

\section{Copyrights}

Copyright for this article is retained by the author(s), with first publication rights granted to the journal.

This is an open-access article distributed under the terms and conditions of the Creative Commons Attribution license (http://creativecommons.org/licenses/by/4.0/). 